\title{
MANAGERIAL EFFICIENCY AND CORPORATE LEVERAGE POLICY IN PAKISTAN
}

\section{Qamar uz Zaman ${ }^{1 *}$, M. Kabir Hassan ${ }^{2 *}$, Hafiz Muhammad Arshad", Sahar Sultan ${ }^{1}$ and Ayesha Ashraf ${ }^{3}$}

\author{
${ }^{1}$ Department of Management Sciences, COMSATS University Islamabad Sahiwal \\ Campus, Off G. T. Road, Sahiwal, Pakistan \\ ${ }^{2}$ Department of Economics and Finance, University of New Orleans, \\ 2000 Lakeshore Dr, New Orleans, LA 70148, United States \\ ${ }^{3}$ Department of Business Administration, University of Sahiwal, \\ Farid Town Rd. Sahiwal, Sahiwal District, Punjab, Pakistan
}

*Corresponding author: mhassan@uno.edu; qamar@cuisahiwal.edu.pk

\begin{abstract}
This study aims to observe the relationship between managerial efficiency (ME) and corporate leverage policy. We use data from Pakistani listed firms from 1999 to 2018. In our stepwise methodology, initially, we used data envelopment analysis (DEA) to acquire firm total efficiency (FTE) scores and then Tobit regression to acquire residual values. These residual values are used as a proxy of ME. After employing various definitions of leverage and fixed effect regression technique, the study observes that ME has a positive and significant relationship with leverage. It indicates that efficient managers are more inclined towards debt financing. It also implies that restraining managerial discretion through debt financing may also make them efficient. Therefore, finding partially approves the agency perspective in the case of Pakistan. Overall, this study offers theoretical contributions to better understand the role of $M E$ and leverage, and the use of DEA approach. Further, this study is fundamental to observe the ME and leverage concerning agency theory in general, and specifically in the context of Pakistan.
\end{abstract}

Keywords: Managerial efficiency, managerial discretion, agency theory, leverage

Publication date: 23 December 2020

To cite this article: Zaman, Q. u., Hassan, M. K., Arshad, H. M., Sultan, S., \& Ashraf, A. (2020). Managerial efficiency and corporate leverage policy in Pakistan. Asian Academy of Management Journal of Accounting and Finance, 16(2), 25-46. https://doi.org/10.21315/aamjaf2020.16.2.2

To link to this article: https://doi.org/10.21315/aamjaf2020.16.2.2

(C) Asian Academy of Management and Penerbit Universiti Sains Malaysia, 2020. This work is licensed under the terms of the Creative Commons Attribution (CC BY) (http://creativecommons. org/licenses/by/4.0/). 


\section{INTRODUCTION}

The researchers in the field of corporate financing policy are underway to savvy the role of unobservable factors in corporate leverage determination (Haron, 2014; Matemilola, Bany-Ariffin, Azman-Saini, \& Nassir, 2018). So far, several firm-specific (Baker \& Wurgler, 2002; Fan, Titman, \& Twite, 2012; Oztekin \& Flannery, 2012; Rajan \& Zingales, 1995; Titman \& Wessels, 1988), country and macro-economic specific factors (Bolton \& Huang, 2017; Hanousek \& Shamshur, 2011; Haron, 2014), have been active to explain the corporate leverage policy. However, these factors remain indecisive to elaborate optimal debt policy. Because the unobservable firm-specific time-invariant factors justify the deviation in firms' capital structure (Lemmon, Roberts, \& Zender, 2008; Matemilola, Bany-Ariffin, \& McGowan, 2013). The bewildering state of corporate leverage determinants stimulates the desire to dilate the investigation to unobservable factors and devise creative solutions (Lemmon et al., 2008). These endeavours are subject to the premise of the optimal capital structure given by Modigliani and Miller (1958).

The problem of unobservable factors is vital and has empirical significance. Responding to the issue of unobservable factors, managerial efficiency (ME) is identified as an import factor (Matemilola et al., 2018). There is an interesting interaction of managerial discretion, efficiency and corporate leverage policy. This study refers to the factor of ME and its impact on corporate leverage policy in the context of managerial discretion. It is argued that debt is helpful to improve the corporate financial discipline catering managerial entrenchment, ensuring their incentive to work in shareholder's interest (Jensen \& Meckling, 1976). Similarly, losing control and reputation, in case of liquidation, stimulates managerial intent to exploit better investment opportunities and manage finances efficiently (Grossman \& Hart, 1982). The regulatory benefit of interest tax shield is indifferent to all managers, but their ability to manage the portfolio of cost of capital and investment decisions may better explain the element of ME.

The existing studies of emerging economies recognise the ability of CEOs and top management to explain the corporate debt financing, supporting their role as per trade-off theory (Alipour, Mohammadi, \& Derakhshan, 2015; Matemilola et al., 2018). In another perspective, the managers are deemed to be efficient while keeping firms solvent with cheaper debt financing. Matemilola et al. (2018) argues that efficient managers materialise the interest tax shield and employ more debt. It is known that higher managerial ability also leads to higher agency problems (Mishra, 2014). The agency theory highlights the issue of managerial entrenchment and suggests optimal leverage policy to restrain the 
managerial discretion (Jensen, 1986). Therefore, the issue of ME and corporate leverage policy seems more relevant to the agency theory. In this context, the paradigm of ME in the corporate capital structure is yet critical in two aspects. First, the possibility of extending the supporting theoretical perspectives. Secondly, the criticality involved in the measurement of managerial ability in capital structure modelling. This article attempts to cover the role of ME in accordance with the agency theory. This perspective indicates the possibility to observe the restrained managerial discretion and their efficiency. In this context, the agency issue seems logically more relevant theoretical perspective to explain the role of ME and managerial discretion in corporate leverage policy.

On the other hand, the literature on corporate financing policy lacks empirical appropriateness to address and measure ME (Gan, 2019; Jahanzeb, Khan, \& Bajuri, 2014; Matemilola et al., 2018). Besides theoretical contribution, this study has enhanced empirical approach to measure ME to explain the corporate leverage policy. This study employs DEA approach to observe the factor of ME (Demerjian, Lev \& Mcvay, 2012). Panel data of Pakistani listed firm for the year 1999 to 2018 has been used for the purpose. The results suggest that $\mathrm{ME}$ has a significantly positive association with corporate leverage in context of agency theory. It indicates that efficient managers employ more debt or more debt makes them efficient. Early empirics support that efficient managers employ more debt considering the benefit of interest tax shield. However, this study argues that common factor of interest tax shield could not explain ME. It is vital to consider debt as a compelling factor to instigate ME. In this context, this study addresses the issue of $\mathrm{ME}$ and corporate financing policy in context of agency perspective. This study is also unique to estimate ME through DEA and observe its relationship with corporate financing policy in general and in context of Pakistan as well.

\section{THEORETICAL FRAMEWORK}

The seminal study of Modigliani and Miller (1958) suggested an optimal financing mix, considering interest tax shield a valuable factor to firm value. Later developments in this field like agency theory, pecking order theory, tradeoff theory, and signaling theory have also attempted to explain the puzzle of corporate capital structure (Matemilola et al., 2018; Olumuyiwa Ganiyu, Adelopo, Rodionova, \& Luqmon Samuel, 2019).

A majority of studies argue that changes in capital structure can be explained by observable characteristics such as profitability, tangibility, growth 
opportunity, size, etc. (e.g., Fan et al., 2012; Hovakimian, Opler, \& Titman, 2001; Frank \& Goyal, 2009; Hijazi \& Tariq, 2006; Rajan \& Zingales, 1995; Ganguli, 2013). A few studies also considered institutional factors (Fan et al., 2012; Oztekin \& Flannery, 2012), macroeconomic factors (Oztekin \& Flannery, 2012; Hanousek \& Shamshur, 2011), employee wages and salaries (Jahanzeb et al., 2014), to explain corporate financing policy. It is revealed that institutional variables, for example, legal system, taxation system, level of corruption and public governance laws also explain the variation in corporate financing policy significantly (Fan et al., 2012). These studies have documented support to all the theories of capital structure. Yet, the attempts to explain the notion of the optimal capital structure remains inconclusive (Ardalan, 2017; Haron, 2014; Zaman, Hassan, Akhter, \& Meraj, 2018).

Therefore, Lemmon et al. (2008) introduced a new paradigm of unobservable firm-specific factors. In the early empirics of corporate capital structure, the unobserved time-invariant factors remain unexplained (Lemmon et al., 2008). In the same vein, Hanousek and Shamshur (2011) stated that dependence and stability of the capital structure are conditioned to the definition and consideration of unobservable firm-specific effects in general. Menichini (2015) also observed that usual determinants or variables of capital structure should be extended to ignored variables to enhance the power and explain the observed variation in leverage. Similarly, Matemilola et al. (2013) found that controlling for time-invariant unobservable factors (fixed effect panel regression) improves the explanatory power of capital structure models. Contextually, ME is very relevant unobserved factor, both in terms of its theoretical and empirical dimensions.

\section{ME, Managerial Discretion and Agency Perspective}

The factor of ME has been defined as one of the unobserved factors in the literature on corporate finance (Matemilola et al., 2018; 2013). The earlier attempts to explore corporate leverage policy in relation to the ME has considered the trade-off, free cash flow (FCF), pecking order and upper-echelons theories (Jensen \& Meckling, 1976; Myers, 1983; Jensen, 1986). The tradeoff theory purposed by Jensen and Meckling (1976) provides positive relationship between firm value and debt ratios considering the balance between debt advantages against debt costs and attain optimal leverage ratio. On the contrary, pecking order theory argues that firms prefer to use internal financing instead of external, and debt instead of equity (Myers, 1983). Later, FCF theory by Jensen (1986) argues that firms with ample FCF and managerial discretion need to tackle conflict of interest between stockholders and managers. 
It is observed that managerial discretion is latitude of actions afforded to the managers. Opportunistic approach of managers forces them to misallocate the financial resources unless restrained by incentives and heavy debt burden. According to Mendoza and Yelpo (2016), managerial discretion influence the corporate leverage. In the same context, Jensen (1986) suggests the optimal leverage policy to restraint the managerial discretion in context of agency theory. According to Jensen and Meckling (1976), Alipour et al. (2015) and Olumuyiwa Ganiyu et al. (2019) leverage may restrain the managerial discretion to the FCF forcing them to choose highly profitable investment opportunities and the efficient utilisation of resources. Further, motivating managers to minify inefficient investment, firm may use high leverage as disciplinary device reducing managerial discretion. The priority of debt repayment in case of liquidation also restrain the managerial discretion (Grossman \& Hart, 1982; Jensen, 1986).

According to Munoz Mendoza and Sepulveda Yelpo (2016) the purpose of debt is to mitigate the effect of managerial discretion. According to Matemilola et al. (2018), efficient managers utilised the benefit of interest tax shield and employ more leverage. Whereas, the present value of the interest tax shield and the cost of financial distress show a zero-sum game to the firm (Zaman et al., 2018). It is argued that interest tax shield results from regulatory policy, framing an equal opportunity for all managers. But, managers ability to carefully handle the cost of capital better explains the ME. Margaritis and Psillaki (2007) supports agency hypothesis and suggested that higher leverage improves the overall firm efficiency and performance. However, his findings are not specific to the ME. In this context, Berger, Ofek, and Yermack (1997) stated that higher managerial entrenchment reduces pressure on managers to take leverage. Thereby, debt is negatively related with managerial discretion. ME has positive relation with debt ratios (Akbari, Salehi, \& Vlashani, 2018).

It means that reducing managerial entrenchment may increase the leverage, so as the managerial ability and efficiency. As mentioned, high ratio of debt restrains the managerial discretion. These arguments indicate that agency perspective is more appropriate to describe the association concerning ME and corporate leverage policy. It is learned that leverage plays a disciplinary role restrain the managerial discretion and enhance their efficiency (Dawar, 2014). Therefore, it could be postulated that restraining managerial discretion could lead to higher leverage and ME. Therefore, following question is relevant; does efficient managers opt for more debt? In this context, the study postulates that there is a positive and significant relationship between ME and corporate leverage. 
H1: ME has significant $\mathrm{p}$ ositive i mpact o $\mathrm{n}$ c orporate financial leverage.

\section{Measurement and Modelling of ME}

The literature of corporate finance discusses $\mathrm{ME} /$ managerial ability in various perspectives. Jahanzeb et al. (2014) investigated the impact of human capital on leverage and found that more the manpower, more the leverage. This study used total salaries and wages as a proxy for human capital. Milbourn (2003) took CEO reputation as a proxy of managerial ability to draw a relationship with stockbased compensation and firm performance. Rajgopal, Shevlin and Zamora (2006) considered CEO's financial press visibility as a measure of managerial ability to relate it with firm performance. Malmendier and Tate (2009) worked with CEO compensation, CEO tenure, number of manager awards from business journals as the measures of ability to estimate the CEO's overconfidence. Gan (2019) employed DEA approach and found managerial ability has positive relation with efficient investment decisions. Andreou et al. $(2015,2017)$ considered residual efficiency and historical returns as a proxy of managerial ability and provide additional evidence on CEO ability and performance in the context of 2008 financial crisis.

Demerjian et al. (2012) proposed a measure of managerial ability, based on managers' efficiency in revenue generation using DEA and found a positive relationship between managerial ability and alternative proxies of managerial ability. Demerjian, Lev, Lewis and Mcvay (2013) also used DEA and found that managers have the ability to manipulate the firm's quality of earnings. Similar method to study the effect of ME on tax avoidance used by Khurana, Moser and Raman, (2018), Koester, Shevlin and Wangerin (2017), and Park, Ko, Jung and Lee (2016).

Although ME is often explained in relation with firm performance however, there are few evidences to assess the relationship between ME and corporate leverage policy. Matemilola et al. (2018) took CEO experience as a proxy of managerial ability revealing its positive relation with debt ratios. Frank and Goyal (2007) also found that higher pay-performance could lead to speedy leverage adjustment. Lan Chen, Hsu and Huang (2010) states that top managers employ more debt. Similarly, Akbari et al. (2018) observed that firms with higher managerial ability have higher adjustment speed towards target leverage. However, Frank and Goyal (2007) state that CEO personal characteristics may not explain the corporate leverage policy. It indicates that only CEO based measure of managerial ability may not explain the overall managerial ability, 
signifying the need to a comprehensive measurement of managerial ability/ efficiency. There is a need of more comprehensive measure to observe the impact of corporate leverage policy and debt-based restrictions on ME i.e., DEA.

\section{METHODOLOGICAL APPROACH}

The measurement of ME is critical to establish a relationship between ME and firm leverage. Generally, CEO related characteristics are used as a proxy to determine the ME e.g., CEO compensation, CEO tenure, experience and media mentions (Francis, Huang, Rajgopal, \& Zang, 2008; Milbourn, 2003; Rajgopal et al., 2006). This study has used ME measurement approach proposed by (Demerjian et al., 2012). This is a two-step approach. At first, it requires to perform DEA to measure the overall firm efficiency. Later, firm specific performance indicators are eliminated to attain the ME scores. These scores are residuals of Tobit regression used to eliminate the firm specific performance and efficiency indicators (Akbari et al., 2018; Demerjian et al., 2013; Jam-e-kausar, Asghar, \& Afza, 2013; Matemilola et al., 2018, 2013; Murthi, Srinivasan, \& Kalyanaram, 1996). Demerjian et al. (2012) found positive correlation between DEA based managerial ability and alternative proxies of managerial ability. Finally, the attained proxy of managerial ability is further used as a regressor to determinant its relationship with leverage.

\section{Sample Size}

This study uses data of non-financial listed firms of Pakistan from 1999 to 2018. The data has been attained from Financial Statement Analysis Reports published by State Bank of Pakistan, and annual reports of the firms.

\section{Data Winsorisation}

We started with 577 firms and 8,655 firm year observations. Table 1 shows the winsorisation of data for further analysis. Initially, we eliminated 131 financial firms with 6,690 firm year observations. Then, we winsorised the firm year observations of missing values of total asset, total sales, and negative equity. After final trimming, the final sample was of 249 firms with 3,735 firm-year observations. 
Table 1

Data winsorisation

\begin{tabular}{lcc}
\hline & No. of firms & Firm year obs. \\
\hline Overall sample & 577 & 147,135 \\
Financial firms & $(131)$ & -33405 \\
Missing values & $(116)$ & -29580 \\
Firms with negative equity & $(81)$ & -20655 \\
Final data & 249 & 63495 \\
\hline
\end{tabular}

Further process and variables are divided in two steps, as given below.

\section{Step 1: DEA}

DEA (non-parametric approach) also known as frontier analysis (Charnes, Cooper, \& Rhodes, 1978). DEA examines relative efficiency of number of entities known as decision making units (DMUs) based on specified inputs and outputs. DEA is effective to estimate the firm efficiency across numerous disciplines (Demerjian et al., 2012): measuring marketing and manufacturing efficiency (Murthi et al., 1996), comparative efficiency (Leverty \& Grace, 2012), and tax avoidance (Akbari et al., 2018). Managerial ability is so far considered to be an unobservable firm specific factor influencing firm's financing decision making (Lemmon et al., 2008; Matemilola et al., 2013). The given approach seems suitable to observe the impact of ME on firm financing behaviour.

Quantifying managerial ability using DEA is further divided in twostep process (Demerjian et al., 2012). Initially, it requires a range of inputs and outputs. The upper bound on DEA efficiency score of a firm on efficient frontier is 1 while the lower bound is 0 . For example, the higher distance from efficient boundary indicates lower efficiency score. Following model is used to measure the firm efficiency (Akbari et al., 2018; Park \& Jung, 2017).

Following is the DEA model to measure overall firm efficiency. The definitions of input (COGS, S GNA, P PE, INTAN) and output (SALES) are described in Appendix A.

$$
\operatorname{Max}_{\theta}=\frac{\text { SALES }}{v_{1} C O G S+v_{2} S G N A+v_{3} P P E+v_{4} I N T A N}
$$

The second step estimates the ME from firm total efficiency (FTE) attained through DEA. The Tobit regression is used to eliminate the effect of firm 
specific efficiency indicators. In this process, dependent variable is DEA firm efficiency score and independent variables are namely; firm size (SIZE), market share (MS), free cash flows (FCF), age of the firm (AGE), and foreign operations (FCI) (Akbari et al., 2018; Demerjian et al., 2012; Park \& Jung, 2017). These firm specific factors can influence the ME. For example, managers of larger firms are in competitive position, compared to the managers in smaller firms. This is also necessary to cover the effect of firm specific factors such as return on assets (ROA) and return on stock (RET). The Tobit regression isolates the ME in the form of residuals of this regression. In another way, the ME remains an unexplained part of this model. The year fixed effect is duly considered in this process. Following are Tobit regression model and definitions of the variables are given in Appendix A.

$\mathrm{FTE}=\beta_{0}+\beta_{1} \mathrm{Size}_{\mathrm{t}}+\beta_{2} \mathrm{MS}_{\mathrm{t}}+\beta_{3} \mathrm{AGE}_{\mathrm{t}}+\beta_{4} \mathrm{FCF}_{\mathrm{t}}+\beta_{6} \mathrm{FCI}+$ Year fixed effect $+\varepsilon$

\section{Step 2: ME and Managerial Discretion}

Finally, the residuals from the Tobit model are considered a proxy of ME. This study considers multiple definitions of leverage to observe the impact of ME on corporate leverage, i.e., total debt to total assets, short-term debt to total assets and long-term debt to total assets indicated by (TDA), (SDA) and (LDA), respectively. As per the agency perspective, higher leverage is considered to show higher managerial entrenchment and vice-versa. Fixed panel regression is used for the purpose. The model comprises of dependent variable leverage ratios, and independent variables $\mathrm{ME}$ and profitability (PROF), fixed assets (FA), firm size (SIZE), growth opportunity (GO) and non-debt tax shield (NDS). The econometric models are as under and related definitions are described in Appendix A.

$$
\begin{array}{rlr}
\mathrm{TDA}_{i t}= & \beta_{0}+\beta_{1} \mathrm{ME}_{i t}+\beta_{2} \mathrm{PROF}_{i t}+\beta_{3} \mathrm{FA}_{i t}+\beta_{4} \mathrm{SIZE}_{i t}+\beta_{5} \mathrm{GO}_{i t}+ & \beta_{6} \mathrm{NDTS}_{i t}+ \\
& \phi_{i}+\varepsilon_{i t}+\alpha_{\mathrm{t}} & (\text { Model 1) } \\
\mathrm{SDA}_{i t}= & \beta_{0}+\beta_{1} \mathrm{ME}_{i t}+\beta_{2} \mathrm{PROF}_{i t}+\beta_{3} \mathrm{FA}_{i t}+\beta_{4} \mathrm{SIZE}_{i t}+\beta_{5} \mathrm{GO}_{i t}+ & \beta_{6} \mathrm{NDTS}_{i t}+\phi_{i} \\
+ & \varepsilon_{i t}+\alpha_{\mathrm{t}} & (\text { Model 2) } \\
\mathrm{LDA}= & \beta_{0}+\beta_{1} \mathrm{ME}_{i t}+\beta_{2} \mathrm{PROF}_{i t}+\beta_{3} \mathrm{FA}_{i t}+\beta_{4} \mathrm{SIZE}_{i t}+\beta_{5} \mathrm{GO}_{i t}+ & \beta_{6} \mathrm{NDTS}_{i t}+\phi_{i} \\
& +\varepsilon_{i t}+\alpha_{\mathrm{t}} & \left(\mathrm{Model}_{3}\right)
\end{array}
$$




\section{RESULTS AND DISCUSSION}

\section{Descriptive Statistics}

Table 2, Panel I presents descriptive statistics of firm efficiency score (FTE), firm size (SIZE), market share (MS), free cash flow indicator (FCF) and foreign operations (FCI). Panel II reports descriptive statistics of leverage proxies.

Table 2

Descriptive statistics

\begin{tabular}{lccccc}
\hline Variables & Mean & Median & Maximum & Minimum & SD \\
\hline Panel I & & & & & \\
FTE & 0.88 & 0.92 & 1.00 & 0.00 & 0.19 \\
SIZE & 15.00 & 13.96 & 19.7 & 2.64 & 1.83 \\
MS & 0.03 & 0.005 & 0.79 & 0.00 & 0.08 \\
FCI & 0.17 & 0.000 & 1.03 & 0.00 & 0.27 \\
FCF & 0.46 & 0.000 & 1.00 & 0.00 & 0.50 \\
Panel II & & & & & \\
STD & 0.42 & 0.40 & 0.90 & 0.00 & 0.19 \\
LTD & 0.14 & 0.07 & 0.78 & 0.00 & 0.17 \\
TD & 0.56 & 0.49 & 1.00 & 0.01 & 0.20 \\
ME & 0.02 & 0.05 & 0.30 & -0.84 & 0.16 \\
PROF & 0.07 & 0.05 & 1.24 & -1.90 & 0.14 \\
NTDS & 0.04 & 0.03 & 2.20 & 0.00 & 0.05 \\
FA & 0.47 & 0.46 & 0.97 & 0.00 & 0.22 \\
GO & 0.14 & 0.07 & 9.88 & -0.74 & 0.32 \\
SIZE & 14.33 & 14.18 & 19.67 & 9.49 & 1.58 \\
\hline
\end{tabular}

Note: Table 2, Panel I presents descriptive statistics of firm efficiency score (FTE), firm size (SIZE), market share (MS), free cash flow indicator (FCF), foreign operations (FCI). Panel II, reports descriptive statistics of leverage proxies, i.e., STD, LTD and TD stands for short term debt ratio, long term debt ratio and total debt ratio, respectively.

Panel II describes the statistics of the variables related to the ME and determinants of capital structure. ME of the sample firms ranges from $(-0.84)$ to (0.30) with mean value of (0.2), indicating the moderate efficiency statistics. The statistics reveal that STD ranges from $(0.00)$ to $(0.90)$ with an average short-term ratio of (0.42). Also, Pakistani listed firms have high STD ratio (Malik \& Afza, $2016)$. The LTD ranges from (0.00) to (0.78) with an average long-term ratio of $(0.14)$. The TD ranges from (0.01) to (1.00) with a mean total leverage of $(0.56)$. 
The lower range of debt indicates the presence of zero leverage firms in Pakistani listed firms (Yasmin \& Rashid, 2019). The value of ME is maximum (0.30) at maximum leverage. The firms enjoy (0.07) of PROF on each unit of total assets having minimum value and standard deviation of $(-1.90)$ and $(0.14)$ respectively. The average GO of sample firms is (0.14) ranging from (9.88) to $(-0.74)$.

\section{Data Envelopment Analysis}

We use an input-oriented variable return to scale (VRS) DEA model to estimate the FTE scores, within an industry (Charnes et al., 1978). Therefore, SALES is considered as an output and COGS, SGNA, PPE and INTAN as inputs to attain DEA firm efficiency scores. Table 3 presents VRS efficiency scores and scale efficiency scores period of 1999-2018.

Table 3

Overall efficiency scores and scale efficiency scores

\begin{tabular}{lcc}
\hline Year & VRS total efficiency score & VRS scale efficiency score \\
\hline 1999 & 0.897 & - \\
2000 & 0.884 & 1.070 \\
2001 & 0.909 & 1.051 \\
2002 & 0.913 & 1.024 \\
2003 & 0.878 & 1.029 \\
2004 & 0.891 & 1.007 \\
2005 & 0.915 & 0.931 \\
2006 & 0.922 & 0.979 \\
2007 & 0.923 & 1.224 \\
2008 & 0.888 & 0.872 \\
2009 & 0.937 & 1.209 \\
2010 & 0.929 & 0.952 \\
2011 & 0.905 & 0.883 \\
2012 & 0.903 & 0.858 \\
2013 & 0.934 & 1.215 \\
2014 & 0.933 & 1.129 \\
2015 & 0.924 & 1.220 \\
2016 & 0.928 & 1.195 \\
2017 & 0.935 & 1.200 \\
\hline & & $($ continued on next page)
\end{tabular}


Table 3: (continued)

\begin{tabular}{ccc}
\hline Year & VRS total efficiency score & VRS scale efficiency score \\
\hline 2018 & 0.938 & 1.212 \\
Total & 0.929 & 1.030 \\
\hline
\end{tabular}

Note: Table 3, reports the yearly efficiency scores for the firms. Firm efficiency is the index ranging from 1 to 0 , where 1 indicates full efficiency and less than or greater than 1 indicates firms' inefficiency. Input oriented model and variable return to scale is applied to measure firm efficiency. Average statistics are shown in this table. VRS TE stands for variable return to scale-total efficiency and VRS SE stands for variable return to scale-scale efficiency.

The scale efficiency (SE) analysis shows how the optimal individual companies use their scales. SE and overall average (1.03), suggesting that nonfinancial firms in Pakistan have been operating on increasing return to scale.

Figure 1 shows efficiency scores for different industries for the period from 1999 to 2018. The figure indicates that only two industries (food and other services) are operating at increasing return to scale while the rest are at decreasing returns to scale. The results of DEA show that merely $18 \%$ firms are relatively efficient in comparison to the other firms and are on the frontier.

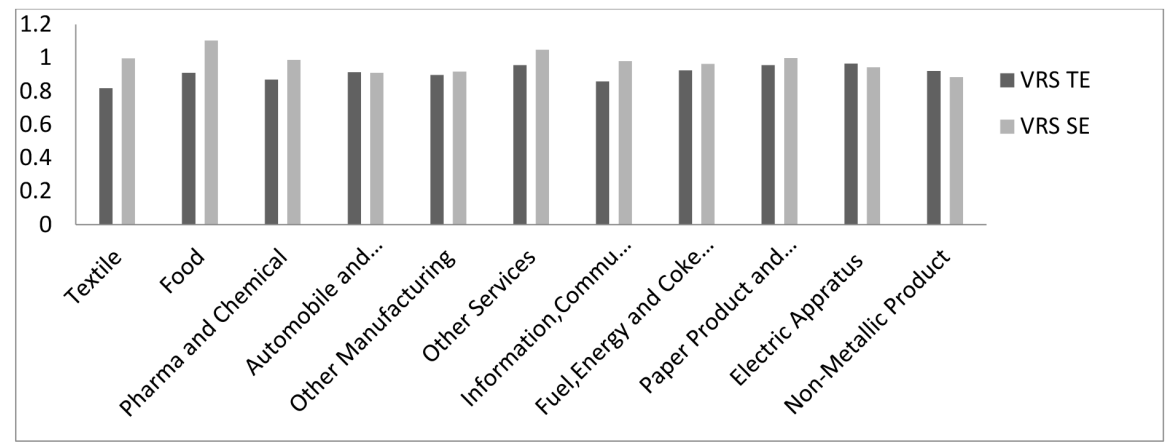

Note: VRS TE stands for variable return to scale-total efficiency and VRS SE stands for variable return to scale-scale efficiency.

Figure 1. Sector Wise Efficiency Scores

\section{Estimation of Managerial Efficiency (ME)}

Tobit regression has been used to regress firm-specific factors on FTE (calculated through DEA in the prior step). Tobit regression is the final step to measure ME. The results of Tobit regression model have been shown in Table 4.

Firm's AGE has significantly s ignificant $(p$-value $=0.062)$ positive $($ coef $=0.008)$ with overall firm e fficiency. The po sitive re lationship indicates 
that as firms mature, efficiency increases. The attained relationship is consistent with the findings of (Castiglione, 2012; Majumdar, 1997; Vijayakumaran \& Vijayakumaran, 2019; Wiwattanakantang, 2001; Yammeesri, 2003). The MS also displays significance ( $p$-value $=0.000$ ) and positive correlation (coef $=$ $0.375)$ with firm efficiency. A greater MS indicates consistent overall firms efficiency (Hansen \& Wernerfelt, 1989). In contrast, firm SIZE displays significance $(p$-value $=0.029)$ and a negative correlation $($ coef $=-0.004)$ relationship with FTE; thus, firms increasing size will reduce the level of its efficiency (Park \& Jung, 2017; Yasuda, 2005). Similarly, the FCF displays significance $(p$-value $=0.000)$ and a negative correlation $($ coef $=-0.039)$ with FTE validating the agency perspective and prior studies (Hong \& Shuting, 2012). It is argued that the issue of agency cost of FCF may lead to poor performance and inefficiencies.

Table 4

Managerial efficiency

\begin{tabular}{lccc}
\hline \multicolumn{2}{l}{ Dependent Variable: FTE Scores } & & \\
\hline Variable & Coefficient & $z$-statistics & $p$-value \\
\hline C & $0.896^{* * *}$ & 33.49 & 0.000 \\
SIZE & $-0.004^{* *}$ & -2.063 & 0.029 \\
MS & $0.375^{* * *}$ & 8.904 & 0.000 \\
FCI & -0.015 & -1.148 & 0.240 \\
AGE & $0.008^{*}$ & 1.778 & 0.062 \\
FCF & $-0.039^{* * *}$ & -6.234 & 0.000 \\
Year fixed effect & & Yes & \\
Industry effect & & Yes \\
\hline
\end{tabular}

Note: Table 4, represents Tobit regression. Firm total efficiency (FTE) regressed with firm specific factors, i.e., firm size (SIZE), market share (MS), foreign operations (FCI), firm age (AGE), free cash flows (FCF). ***, **, * indicates $1 \%, 5 \%$ and $10 \%$ level of significance level, respectively.

Tobit regression isolates the unobserved factor of ME after controlling for the overserved firm efficiency indicators, i.e., SIZE, MS, FCI, AGE and FCF. The residual values/scores from the Tobit regression are now considered suitable proxy to measure ME and pursue further analysis (Park et al., 2016).

\section{Regression Analysis}

A fixed effects model is used to determine the relationship between ME and leverage. A Hausman test is used to choose a suitable model (Greene, 2002) in 
Table 5. The significant probability values in Column 2 indicate that a fixed effect model is appropriate for the selected data set.

Table 5

Model selection

\begin{tabular}{lcc}
\hline \multicolumn{2}{l}{ Correlated random effects - Hausman test } & \\
\hline Test summary & Chi-square statistic (1) & Prob. (2) \\
\hline $\begin{array}{l}\text { Model 1: TDA and ME } \\
\text { Cross-section random }\end{array}$ & 21.9 & 0.0013 \\
$\begin{array}{l}\text { Model 2: LDA and ME } \\
\text { Cross-section random }\end{array}$ & \\
$\begin{array}{l}\text { Model 3: SDA and ME } \\
\text { Cross-section random }\end{array}$ & 67.07 & 0.0000 \\
\hline
\end{tabular}

Note: Table 5, presents the results of Hausman test, null hypothesis is rejected at $(p<0.01)$. Column 2 indicate fixed effect approach is better. Three different models are used to test the best fit. Model 1 based on total debt/total assets, Model 2 based on long term debt/total asset and Model 3 having short term debt/total assets.

Table 6 reports the results for fixed effect panel regressions using different leverage proxies, i.e., TDA, LDA and SDA presented in Columns 1,2 and 3, respectively. As indicated in the Table 6, the industry and year fixed effects are duly considered. The results indicate that ME and strongly significantly and positive relationship $(0.07,0.03$ and 0.04$)$ with all the proxies of leverage consistent with prior study (Matemilola et al., 2018). It depicts that efficient managers tend employ more leverage. The SIZE also has significantly positive relationship $(0.06,0.04$ and 0.02$)$ with all the proxies of leverage at 0.05 level of significance. It indicates that efficient managers with larger size firms are also inclined to take more leverage (Frank \& Goyal, 2007; Friend \& Lang, 1988; Matemilola et al., 2018). More or less the positively significant relationship (0.04) of GO with LDA indicates that growing firms also take more leverage. On contrary, the coefficient values of $(-0.30,-0.08$ and -0.22$)$ PROF show significantly negative relationship with all the measures of leverage. As the pecking order theory advocates that firms with high profitability prefer to use internal funds over leverage (Myers, 1983). The inconsistently significant results of NDTS with negative relationship $(-0.05,-0.08)$ are consistent with the findings of earlier studies (Haron, 2014; Jahanzeb et al., 2014). Overall, the results are consistent with the findings of (Baker \& Wurgler, 2002; Frank \& Goyal, 2009; Hovakimian et al., 2001; Matemilola et al., 2018; Olumuyiwa Ganiyu et al., 2019; Rajan \& Zingales, 1995; Titman \& Wessels, 1988). 
Table 6

$M E$ and leverage

\begin{tabular}{lccc}
\hline \multirow{2}{*}{ Variable } & $(1)$ & $(2)$ & $(3)$ \\
\cline { 2 - 4 } & TDA & LDA & SDA \\
\hline ME & $0.07^{* * *}$ & $0.03^{* * *}$ & $0.04^{* * *}$ \\
PROF & $(4.87)$ & $(2.45)$ & $(2.88)$ \\
& $-0.30^{* * *}$ & $-0.08^{* * *}$ & $-0.22^{* * *}$ \\
SIZE & $(-17.4)$ & $(-5.85)$ & $(-12.7)$ \\
& $0.06^{* * *}$ & $0.04^{* * *}$ & $0.02^{* * *}$ \\
FA & $(11.7)$ & $(8.89)$ & $(4.63)$ \\
& $-0.06^{* * *}$ & $0.20^{* * *}$ & $-0.25^{* * *}$ \\
GO & $(-3.12)$ & $(12.87)$ & $(-13.13)$ \\
& 0.0005 & $0.004^{* *}$ & -0.004 \\
NDTS & $(0.78)$ & $(2.15)$ & $(-0.10)$ \\
& -0.05 & $-0.08^{* *}$ & 0.03 \\
$R^{2}$ & $(-1.23)$ & $(-2.35)$ & $(0.77)$ \\
Adjusted $R^{2}$ & 0.69 & 0.57 & 0.62 \\
F-test & 0.67 & 0.52 & 0.59 \\
Observations & $28.25^{* * *}$ & $16.23^{* * *}$ & $20.98^{* * *}$ \\
Cross section fixed effect & 3735 & 3735 & 3735 \\
Year fixed effect & Yes & Yes & Yes \\
Industry fixed effect & Yes & Yes & Yes \\
\hline
\end{tabular}

Note: Table 6, reports three econometric models are used to test $\mathrm{H} 1$ the impact of ME on leverage. Here, main variable of interest is ME that negate $\mathrm{H} 1$ is accepted, controlled variables are profit (PROF), firm size (SIZE), firm fixed assets (FA), growth opportunity (GO) and non-debt tax shield (NTDS). In the table, (1) indicate the Model 1 based on total debt/total assets (TDA), (2) refers to Model 2 based on long term debt/total asset (LDA) and (3) indicate Model 3 having short term debt/total assets (SDA) used as dependent variables. ${ }^{* * *}$ and ${ }^{* *}$ indicates 0.01 and 0.05 level of significance level respectively.

The $R^{2}$ for Models 1, 2 and 3 are 0.69, 0.57 and 0.62, respectively, signalling that the variability of ME has improved the explanatory power of capital structure model (approximately $60 \%$ in each case). At the same time, the $F$-test statistics of each model $(28.25,16.23$ and 20.98, respectively) indicate overall model fitness. 


\section{DISCUSSION}

The results of our research reveal that ME has significant positive impact on corporate leverage which is consistent with agency theory. It is evident that efficient managers employ more debt (Matemilola et al., 2018). At the same time, it is also observed that higher ME leads to higher agency issues (Mishra, 2014). In this regard, agency theory suggests optimal leverage policy to solve these agency issues through restrained managerial discretion. According to our results both of the firms with larger size and growth potential employ more leverage to hinder managerial discretion. Otherwise stated, leverage is a useful tool to restrain managerial discretion - in context of agency theory (Jensen \& Meckling, 1976) - and enforce efficiency upon corporate managers. As larger firms see higher amounts of FCF, there is more motive to restrain the managerial discretion by employing more debt (Olumuyiwa Ganiyu et al., 2019). In addition, growth objective is very critical to managerial perspective and to corporate leverage policy. The managers have to align their capabilities and financing mix in accordance with tentative growth targets. Therefore, they are assumed to have higher leverage and utilise it efficiently. In this context, result support the agency perspective considering that larger firms also have greater possibility of issuing debt because of low bankruptcy risk (Hijazi \& Tariq, 2006). Besides this, it is also important to consider that interest tax shield motivate managers to materialise the cheaper cost of debt financing, in order to improve the firm profitability. This is another factor vital to link the ME, and ME. But the interest tax shield is commonly available subsidy to all managers, thereby, insignificant to be considered as a single factor. So, managers skills to manage the cost of capital batter explain ME. Therefore, we argue that agency theory may better explain the phenomenon of ME as a determinant of corporate capital structure in context with managerial desertion. But in this case, it is duly considerable that restraining managerial discretion has the motive to make them debt efficient rather wise decision makers. Managers must forgo viable investment projects to meet the cost of debt capital and survive with the fear of fixed financing charges. In this case, the leverage plays a vital role to keep managers efficient through restraining their financing and investment discretion. Therefore, the agency perspective provides a viable ground to explain the association of ME and corporate leverage. But whole discussion retains a very important question for further consideration; does restraining managerial discretion makes them more efficient or efficient managers employ more debt? 


\section{CONCLUSION}

This study attempts to investigate the impact of ME on corporate leverage policy in Pakistan. The study used the data of non-financial listed firms of Pakistan for the year 1999 to 2018. This study considers DEA to measure the FTE and ME. Also, while efficient managers have higher tendency towards debt financing, higher leverage stretches the $\mathrm{ME}$ to meet the shareholders expectations and fixed charges. However, higher managerial ability leads to higher agency problems (Mishra, 2014). In such cases, debt is used to mitigate the managerial discretions. Conclusively, it is observed that positive relationship of $\mathrm{ME}$ and corporate leverage has more relevance to managerial discretion and agency theory in Pakistani firms. The results of the study are in line with the finding of (Akbari et al., 2018; Matemilola et al., 2018). However, this study offers theoretical contributions to better understand the role of ME and leverage and the use of DEA approach. Further, this study is fundamental to observe the ME and leverage concerning agency theory in general and specifically in the context of Pakistan.

For future research, more variables related to firm efficiency using the Tobit model must be employed. The casual effect of leverage and ME as well as mediating role of managerial discretion will provide important theoretical insights in future research. 


\section{APPENDIX A}

\section{Variables Description}

\begin{tabular}{|c|c|c|c|}
\hline Variables & Definitions & Sign & Expected Sign \\
\hline \multicolumn{4}{|c|}{ Panel I: DEA approach } \\
\hline SALES & Operating revenue & & \\
\hline COGS & Cost of goods sold & & \\
\hline SGNA & Sales and general administrative expenses & & \\
\hline$P P E$ & Tangible assets (property, plant and equipment) & & \\
\hline INTAN & Intangible assets & & \\
\hline \multicolumn{4}{|c|}{ Panel II: Tobit regression } \\
\hline FTE & $\begin{array}{l}\text { Firm total efficiency, the firm efficiency measured by } \\
\text { DEA }\end{array}$ & & \\
\hline Size & Natural log of total assets & - & - \\
\hline MS & Firm revenue/total industry revenue & + & + \\
\hline FCF & $\begin{array}{l}\text { Free cash flow }=1 \text { if free cash flow (net income before } \\
\text { depreciation }- \text { change in operating capital }- \text { capital } \\
\text { expenditure) }>0 \text {, otherwise } 0 \text {. }\end{array}$ & - & - \\
\hline$A G E$ & $\begin{array}{l}\text { Natural log of (the number of years the firm has been } \\
\text { listed }+1 \text { ) }\end{array}$ & + & + \\
\hline FCI & $\begin{array}{l}\text { Foreign operations, the absolute magnitude of foreign } \\
\text { currency translation accounts (foreign currency gain, } \\
\text { foreign currency translation loss, gain on foreign currency } \\
\text { transactions, loss on foreign currency transactions)/total } \\
\text { revenue. }\end{array}$ & - & - \\
\hline TDAit & The ratio of total debt to total assets for $i$ firm and $t$ time & + & + \\
\hline SDAit & $\begin{array}{l}\text { The ratio of short-term debt to total assets for the } i \text { firm } \\
\text { and } t \text { time }\end{array}$ & + & + \\
\hline LDAit & $\begin{array}{l}\text { The ratio of long-term debt to total assets for the } i \text { firm } \\
\text { and } t \text { time }\end{array}$ & + & + \\
\hline$M E_{i t}$ & Managerial efficiency for $i$ firm and $t$ time & + & + \\
\hline$P R O F_{i t}$ & Profit for $i$ firm and $t$ time & - & - \\
\hline$F A_{i t}$ & Fixed assets for $i$ firm and $t$ time & $+/-$ & - \\
\hline$S I Z E_{i t}$ & Natural $\log$ of total assets for $i$ firm and $t$ time & + & + \\
\hline$G O_{i t}$ & Growth opportunity for $i$ firm and $t$ time & $+/-$ & + \\
\hline$N T D S_{i t}$ & Non-debt tax shield for $i$ firm and $t$ time & $+/-$ & - \\
\hline$\phi_{i}$ & Industry fixed effect & & \\
\hline$\varepsilon_{i t}$ & Residuals or error term & & \\
\hline$\alpha_{t}$ & The year fixed effect & & \\
\hline
\end{tabular}




\section{REFERENCES}

Akbari, F., Salehi, M., \& Vlashani, M. A. B. (2018). The effect of managerial ability on tax avoidance by classical and Bayesian econometrics in multilevel models: Evidence of Iran. International Journal of Emerging Markets, 13(6), 1656-1678.

Alipour, M., Mohammadi, M. F. S., \& Derakhshan, H. (2015). Determinants of capital structure: An empirical study of firms in Iran. International Journal of Law and Management, 57(1), 53-83. https://doi.org/10.1108/IJLMA-01-2013-0004

Andreou, P. C., Ehrlich, D., Karasamani, I., \& Louca, C. (2015). Managerial ability and firm performance: Evidence from the global financial crisis. SSRN Electronic Journal. https://doi.org/10.2139/ssrn.2633216

Andreou, P. C., Karasamani, I., Louca, C., \& Ehrlich, D. (2017). The impact of managerial ability on crisis-period corporate investment. Journal of Business Research, 79(May), 107-122. https://doi.org/10.1016/j.jbusres.2017.05.022

Ardalan, K. (2017). Capital structure theory: Reconsidered. Research in International Business and Finance, 39, 696-710. https://doi.org/10.1016/J.RIBAF.2015.11.010

Baker, M., \& Wurgler, J. (2002). Market timing and capital structure. The Journal of Finance, 57(1), 1-32.

Berger, P. G., Ofek, E. L. I., \& Yermack, D. L. (1997). Managerial entrenchment and capital structure decisions. The Journal of Finance, 52(4), 1411-1438. https://doi. org/10.1111/j.1540-6261.1997.tb01115.x

Bolton, P., \& Huang, H. (2017). The capital structure of nations. Review of Finance, 22(1), 1-38. https://doi.org/10.1093/rof/rfx042

Castiglione, C. (2012). Technical efficiency and ICT investment in Italian manufacturing firms. Applied Economics, 44(14), 1749-1763. https://doi.org/10.1080/00036846 .2011 .554374

Charnes, A., Cooper, W. W., \& Rhodes, E. (1978). Measuring the efficiency of decision making units. European Journal of Operational Research, 2, 429-444.

Dawar, V. (2014). Agency theory, capital structure and firm performance: Some Indian evidence. Managerial Finance, 40(12), 1190-1206.

Demerjian, P., Lev, B., \& Mcvay, S. (2012). Quantifying managerial ability: A new measure and validity tests. Management Science, 58(7), 1229-1248.

Demerjian, P. R., Lev, B., Lewis, M. F., \& Mcvay, S. E. (2013). Managerial ability and earnings quality. The Accounting Review, 88(2), 463-498. https://doi.org/10.2308/ accr-50318

Fan, J. P. H., Titman, S., \& Twite, G. (2012). An international comparison of capital structure and debt maturity choices. Journal of Financial and Quantitative Analysis, 47(1), 23-56. https://doi.org/10.1017/S0022109011000597

Francis, J., Huang, A. H., Rajgopal, S., \& Zang, A. Y. (2008). CEO reputation and earnings quality. Contemporary Accounting Research, 25(1), 109-147.

Frank, M. Z., \& Goyal, V. K. (2007). Corporate leverage: How much do managers really matter? Retrieved from http://ssrn.com/abstract $=971082$

Frank, M. Z., \& Goyal, V. K. (2009). Capital structure decisions: Which factors are reliably important? Financial Management, 38(1), 1-37. 
Friend, I., \& Lang, L. H. P. (1988). An empirical test of the impact of managerial selfinterest on corporate capital structure. The Journal of Finance, 43(2), 271-281.

Gan, H. (2019). Does CEO managerial ability matter? Evidence from corporate investment efficiency. Review of Quantitative Finance and Accounting, 1085-1118. https:// doi.org/10.1007/s11156-018-0737-2

Ganguli, S. K. (2013). Capital structure - does ownership structure matter? Theory and Indian evidence. Studies in Economics and Finance, 30(1), 56-72. https://doi. org/10.1108/10867371311300982

Greene, W. H. (2002). Econometric analysis (5th ed.). Upper Saddle River, NJ: Prentice Hall.

Grossman, S. J., \& Hart, O. D. (1982). Corporate financial structure and managerial incentives (Vol. I). Chicago: University of Chicago Press.

Hanousek, J., \& Shamshur, A. (2011). A stubborn persistence: Is the stability of leverage ratios determined by the stability of the economy? Journal of Corporate Finance, 17(5), 1360-1376.

Hansen, G. S., \& Wernerfelt, B. (1989). The determinants of firm performance: Of economic and relative importance factors. Strategic Management Journal, 10(5), 399-411.

Haron, R. (2014). Capital structure inconclusiveness: Evidence from Malaysia, Thailand and Singapore. International Journal of Managerial Finance, 10(1), 23-38. https://doi.org/10.1108/IJMF-03-2012-0025

Hijazi, S. T., \& Tariq, Y. (2006). Determinants of capital structure: A case for the Pakistani cement industry. Lahore Journal of Economics, 11(1), 63-80.

Hong, Z., \& Shuting, Y. (2012). Relationship between free cash flow and financial performance evidence from the listed real estate companies in China. Paper presented at The 2012 International Conference on Innovation and Information Management (Vol. 36, pp. 331-335), 7-8 January, Chengdu, China.

Hovakimian, A., Opler, T., \& Titman, S. (2001). The debt-equity choice. The Journal of Financial and Quantitative Analysis, 36(1), 1-24.

Jahanzeb, A., Khan, S., \& Bajuri, N. H. (2014). Determinants of capital structure and human capital. International Journal of Information Processing and Management, 5(4), 114-123.

Jam-e-kausar, M., Asghar, A., \& Afza, T. (2013). Efficiency of modaraba and leasing companies in Pakistan. Middle-East Journal of Scientific Research, 17(3), 305314. https://doi.org/10.5829/idosi.mejsr.2013.17.03.13305

Jensen, M. C. (1986). Agency costs of free cash flow, corporate finance, and takeovers. The American Economic Review, 76(2), 323-329.

Jensen, M. C., \& Meckling, W. H. (1976). Theory of the firm: Managerial behavior, agency costs and ownership structure. Journal of Financial Economics 3(4), 305-360.

Khurana, I. K., Moser, W. J., \& Raman, K. K. (2018). Tax avoidance, managerial ability, and investment efficiency. Journal of Accounting, Finance and Business Studies, 54(4), 547-575.

Koester, A., Shevlin, T., \& Wangerin, D. (2017). The role of managerial ability in corporate tax avoidance. Management Science, 63(10), 3285-3310. https://doi.org/10.1287/ mnsc. 2016.2510 
Lan Chen, H., Hsu, W.-T., \& Huang, Y.-S. (2010). Top management team characteristics, R\&D investment and capital structure in the IT industry. Small Business Economics, 35, 319-333. https://doi.org/10.1007/s11187-008-9166-2

Lemmon, M. L., Roberts, M. R., \& Zender, J. F. (2008). Back to the beginning: Persistence and the cross-section of corporate capital structure. The Journal of Finance, 63(4), 1575-1608. https://doi.org/10.1111/j.1540-6261.2008.01369.x

Leverty, J. T., \& Grace, M. F. (2012). Dupes or incompetents? An examination of management's impact on firm distress. The Journal of Risk and Insurance, 79(3), 751-783. https://doi.org/10.1111/j.1539-6975.2011.01443.x

Majumdar, S. K. (1997). The impact of size and age on firm-level performance: Some evidence from India. Review of Industrial Organization, 12, 231-241.

Malik, Q. U. Z., \& Afza, T. (2016). Do group affiliated firms specialize in debt? Evidence from Pakistan. Journal of Economic and Administrative Sciences, 32(1), 46-62. https://doi.org/10.1108/JEAS-07-2015-0020

Malmendier, U., \& Tate, G. (2009). Superstar CEOs. Quarterly Journal of Economics, $124,1593-1638$.

Margaritis, D., \& Psillaki, M. (2007). Capital structure and firm efficiency. Journal of Business Finance and Accounting, 34(9-10), 1447-1469. https://doi.org/10.1111/ j.1468-5957.2007.02056.x

Matemilola, B. T., Bany-Ariffin, A. N., Azman-Saini, W. N. W., \& Nassir, A. M. (2018). Does top managers' experience affect firms' capital structure? Research in International Business and Finance, 45, 488-498. https://doi.org/10.1016/j. ribaf.2017.07.184

Matemilola, B. T., Bany-Ariffin, A. N., \& McGowan, C. B. (2013). Unobservable effects and firm's capital structure determinants. Managerial Finance, 39(12), 11241137. https://doi.org/10.1108/MF-08-2012-0187

Menichini, A. (2015). On the determinants of firm leverage: Evidence from a structural estimation. International Journal of Managerial Finance, 11(2), 179-197. https:// doi.org/10.1108/IJMF-04-2014-0054

Milbourn, T. T. (2003). CEO reputation and stock-based compensation. Journal of Financial Economics, 68, 233-262. https://doi.org/10.1016/S0304405X(03)00066-7

Mishra, D. R. (2014). The dark side of CEO ability: CEO general managerial skills and cost of equity capital. Journal of Corporate Finance, 29, 390-409. https://doi. org/10.1016/j.jcorpfin.2014.10.003

Modigliani, F., \& Miller, M. H. (1958). The cost of capital, corporation finance and the theory of investment. The American Economic Review, 48(3), 261-297.

Munoz Mendoza, J. A., \& Sepulveda Yelpo, S. M. (2016). Does managerial discretion affect debt maturity in Chilean firms? An agency cost and asymmetric information approach. Ecos De Economía: A Latin American Journal of Applied Economics, 20(43), 65-87. https://doi.org/10.17230/ecos.2016.43.4

Murthi, B. P. S., Srinivasan, K., \& Kalyanaram, G. (1996). Controlling for observed and unobserved managerial skills in determining first-mover market share advantages. Journal of Marketing Research, 33(3), 329-336.

Myers, S. C. (1983). The capital structure puzzle. The Journal of Finance, 3, 575-592. 
Olumuyiwa Ganiyu, Y., Adelopo, I., Rodionova, Y., \& Luqmon Samuel, O. (2019). Capital structure and firm performance in Nigeria. African Journal of Economic Review, $7(1), 31-56$.

Oztekin, O., \& Flannery, M. J. (2012). Institutional determinants of capital structure adjustment speeds. Journal of Financial Economics, 103, 88-112. https://doi. org/10.1016/j.jfineco.2011.08.014

Park, J., Ko, C. Y., Jung, H., \& Lee, Y. (2016). Managerial ability and tax avoidance: Evidence from Korea. Asia-Pacific Journal of Accounting \& Economics, 23(4), 449-477. https://doi.org/10.1080/16081625.2015.1017590

Park, S. Y., \& Jung, H. (2017). The effect of managerial ability on future stock price crash risk: Evidence from Korea. Sustainability, 9(12), 1-17. https://doi.org/10.3390/ su9122334

Rajan, R. G., \& Zingales, L. (1995). What do we know about capital structure? Some evidence from international data. The Journal of Finance, 50(5), 1421-1460.

Rajgopal, S., Shevlin, T., \& Zamora, V. (2006). CEOs' outside employment opportunities and the lack of relative performance. The Journal of Finance, 61(4), 1813-1844.

Titman, S., \& Wessels, R. (1988). The determinants of capital structure choice. The Journal of Finance, 43(1), 1-19.

Vijayakumaran, R., \& Vijayakumaran, S. (2019). Leverage, debt maturity and corporate performance: Evidence from Chinese listed companies. Asian Economic and Financial Review, 9(4), 491-506. https://doi.org/10.18488/journal. aefr.2019.94.491.506

Wiwattanakantang, Y. (2001). Controlling shareholders and corporate value: Evidence from Thailand. Pacific-Basin Finance Journal, 9, 323-362.

Yammeesri, J. (2003). Corporate governance: Ownership structure and firm performanceevidence from Thailand. [Doctoral dissertation, University of Wollongong]. University of Wollongong thesis collection 1954-2016. https://ro.uow.edu.au/ cgi/viewcontent.cgi? article $=2908 \&$ context $=$ theses

Yasmin, A., \& Rashid, A. (2019). On the mystery of financial conservatism: Insights from Pakistan. Emerging Markets Finance and Trade, 55(12), 2904-2927. https://doi. org/10.1080/1540496X.2018.1553158

Yasuda, T. (2005). Firm growth, size, age and behavior in Japanese manufacturing. Small Business Economics, 24, 1-15.

Zaman, Q. u., Hassan, M. K., Akhter, W., \& Meraj, M. A. (2018). From interest tax shield to dividend tax shield: A corporate financing policy for equitable and sustainable wealth creation. Pacific-Basin Finance Journal, 52, 144-162. https://doi. org/10.1016/j.pacfin.2017.01.003 